\title{
Seasonal and interannual dynamics of soil microbial biomass and available nitrogen in an alpine meadow in the eastern part of Qinghai-Tibet Plateau, China
}

\author{
Bo $\mathrm{Xu}^{1,2}$, Jinniu Wang ${ }^{1,3}$, Ning $\mathrm{Wu}^{1,3}$, Yan $\mathrm{Wu}^{1,3}$, and Fusun Shi ${ }^{1,3}$ \\ ${ }^{1}$ Chengdu Institute of Biology, Chinese Academy of Sciences, Chengdu 610041, China \\ ${ }^{2}$ College of Resources and Environment, Aba Teachers University, Aba, Sichuan 623002, China \\ ${ }^{3}$ Key Laboratory of Mountain Ecological Restoration and Bioresource Utilization \& Ecological Restoration Biodiversity \\ Conservation Key Laboratory of Sichuan Province, Chinese Academy of Sciences, Chengdu 610041, China
}

Correspondence: Fusun Shi (shifs@ cib.ac.cn)

Received: 25 February 2017 - Discussion started: 27 March 2017

Revised: 22 November 2017 - Accepted: 11 December 2017 - Published: 29 January 2018

\begin{abstract}
Soil microbial activity varies seasonally in frozen alpine soils during cold seasons and plays a crucial role in available $\mathrm{N}$ pool accumulation in soil. The intra- and interannual patterns of microbial and nutrient dynamics reflect the influences of changing weather factors, and thus provide important insights into the biogeochemical cycles and ecological functions of ecosystems. We documented the seasonal and interannual dynamics of soil microbial and available $\mathrm{N}$ in an alpine meadow in the eastern part of Qinghai-Tibet Plateau, China, between April 2011 and October 2013. Soil was collected in the middle of each month and analyzed for water content, microbial biomass $\mathrm{C}(\mathrm{MBC})$ and $\mathrm{N}(\mathrm{MBN})$, dissolved organic $\mathrm{C}$ and $\mathrm{N}$, and inorganic N. Soil microbial community composition was measured by the dilutionplate method. Fungi and actinomycetes dominated the microbial community during the nongrowing seasons, and the proportion of bacteria increased considerably during the early growing seasons. Trends of consistently increasing MBC and available $\mathrm{N}$ pools were observed during the nongrowing seasons. MBC sharply declined during soil thaw and was accompanied by a peak in available $\mathrm{N}$ pool. Induced by changes in soil temperatures, significant shifts in the structures and functions of microbial communities were observed during the winter-spring transition and largely contributed to microbial reduction. The divergent seasonal dynamics of different $\mathrm{N}$ forms showed a complementary nutrient supply pattern during the growing season. Similarities between the interannual dynamics of microbial biomass and available $\mathrm{N}$ pools were observed, and soil temperature and water conditions
\end{abstract}

were the primary environmental factors driving interannual fluctuations. Owing to the changes in climate, seasonal soil microbial activities and nutrient supply patterns are expected to change further, and these changes may have crucial implications for the productivity and biodiversity of alpine ecosystems.

\section{Introduction}

In Arctic and alpine ecosystems, soil microbial activity plays a crucial role in soil $\mathrm{C}$ and $\mathrm{N}$ cycles and nutrient transformation in frozen soils during cold seasons (Lipson et al., 1999; Murata et al., 1999; Panikov et al., 2006; Larsen et al., 2007; Matthew Robson et al., 2010). Unfortunately, information on belowground microbial activities and nutrient cycles in both growing and nongrowing seasons in such ecosystems are limited. Moreover, intra-annual biogeochemical cycles affected by the changes in seasonal weather factors in frozen regions are not fully understood. The integration between the intra- and interannual patterns in soil microbial and biogeochemical dynamics has important implications for the exploration of the current and future impacts of climate change on the functions of cold ecosystems (Edwards and Jefferies, 2013).

Microorganisms in alpine environments covered seasonally with snow can survive in thin unfrozen water films when most of the soil water is frozen (Brooks et al., 1996; Jefferies et al., 2010). Previous studies indicated that substantial mi- 
crobial activity exists in frozen soils during cold seasons even at temperatures lower than $-5^{\circ} \mathrm{C}$ (Brooks et al., 1996; Edwards et al., 2006; Panikov et al., 2006; Jefferies et al., 2010). Although microbial activity is limited by cold temperatures and substrate transport (Deming, 2002; Lipson et al., 2002; Oquist et al., 2009), its cumulative effects on organic matter decomposition in soil during long cold seasons significantly influence annual $\mathrm{N}$ pools in Arctic and alpine ecosystems (Lipson et al., 1999; Schmidt and Lipson, 2004; Schmidt et al., 2007; Buckeridge and Grogan, 2008). Thus, by understanding microbial activities in winter, we can broaden our current knowledge regarding nutrient supplies for plants and microbes during the subsequent growing season.

Previous studies suggested that the fungal/bacterial ratio of a soil microbial community in winter is higher than that in summer (Lipson et al., 2002; Schadt et al., 2003), and significant shifts in microbial community structures and functions occur during soil thawing in Arctic and alpine tundra (Lipson et al., 2002; Schadt et al., 2003; Lipson and Schmidt, 2004; Buckeridge et al., 2013). Apart from these changes, the rate of microbial biomass turnover increases during winterspring transition periods (Edwards et al., 2006; Schmidt et al., 2007; Edwards and Jefferies, 2013; Buckeridge et al., 2013). Furthermore, available $C$ substrates for microbial communities change from winter to summer. For example, winter microbes use dead plant materials, whereas plant root exudates supply available $\mathrm{C}$ for summer microbes (Lipson et al., 2002; Schmidt et al., 2007). These changes in microbial communities changes might play key roles in controlling annual patterns of nutrient cycling and plant $\mathrm{N}$ uptake in Arctic and alpine ecosystems (Schmidt et al., 2007; Buckeridge and Grogan, 2008; Buckeridge et al., 2013).

In Arctic and alpine soils, microbial biomass and available $\mathrm{N}$ pools increase in winter, followed by the reduction in microbial biomass during winter-spring transition when the soil thaws (Brooks et al., 1998; Lipson et al., 1999; Schmidt and Lipson, 2004; Miller et al., 2009). Decrease in microbial biomass is linked to a sudden rise in $\mathrm{N}$ availability during soils thawing, as observed in alpine ecosystems (Brooks et al., 1998; Lipson et al., 1999; Schmidt et al., 2007; Yang et al., 2016). The release of soluble $\mathrm{N}$ from microbial biomass during soil-thawing periods provides an important available $\mathrm{N}$ source to plants, particularly in N-limited ecosystems (Lipson et al., 1999; Miller et al., 2009; Buckeridge and Grogan, 2010). However, despite ample evidence of soil microbial activity and nutrient mineralization during winter and/or summer months in Arctic and alpine regions (Edwards et al., 2006; Schmidt et al., 2007; Miller et al., 2009; Edwards and Jefferies, 2013; Buckeridge et al., 2013), studies that explore the changes in microbial and $\mathrm{N}$ pools in alpine ecosystems during summer and winter across several years are few. Thus, the annual patterns of microbial biomass and $\mathrm{N}$ pools in alpine ecosystems and their responses to seasonal and interannual weather variations remain unclear.
In this study, we documented the seasonal dynamics of soil microbial biomass and available $\mathrm{N}$ for 3 years in an alpine meadow in the eastern part of Qinghai-Tibet Plateau of China to address the following questions:

1. What are the soil microbial and available $\mathrm{N}$ dynamics during the growing and nongrowing seasons in the alpine meadow?

2. What are the interannual patterns of soil microbial and available $\mathrm{N}$ dynamics in the alpine meadow?

3. What environmental factors affect these dynamics?

4. What are the relationships between soil microbial biomass and available $\mathrm{N}$ pools in seasonally frozen ecosystems?

\section{Material and methods}

\subsection{Site description}

The study was performed in the alpine belt of Songpan County, which belongs to the Min Mountains in the eastern part of the Qinghai-Tibet Plateau, China. According to the records from a meteorological station $\left(33^{\circ} 1^{\prime} \mathrm{N}, 103^{\circ} 41^{\prime} \mathrm{E}\right.$, $3600 \mathrm{~m}$ a.s.l.) near the study area, the average monthly air temperatures range from $-7.6{ }^{\circ} \mathrm{C}$ in January to $15.5^{\circ} \mathrm{C}$ in August. The annual precipitation is $718 \mathrm{~mm}, 70 \%$ of which occurs from June to August. The region has no absolute frostfree period, and snowfall usually occurs from late September to early May. Persistent snow cover usually occurs from late December to early April, and the mean snow depth is $16.58 \mathrm{~cm}$ in the study area (Bo Xu, unpublished data, collected in 2012, 2013). The alpine vegetation community has rich species composition and is dominated by different plant species during the growing season (i.e., during early May to late October according to the plant phenology observation in the alpine meadow from 2011 to 2013). Early flowering plants, such as Primula sikkimensis, Androsace umbellata, and Caltha palustris, dominate the community as soon as the snow melts; Polygonum macrophyllum, Ranunculus tanguticus, and Carex melanocephala dominate the middle growing season; and Saussurea hieracioides and Gentiana sinoornata usually dominate the late growing season (Bo Xu, unpublished data, collected from 2011 to 2013). The predominant soil type is mountain dark brown soil and Mat Cry-gelic Cambisols (i.e., silty loam inceptisol; Chinese Soil Taxonomy Research Group, 1995; Soil Survey Staff, 2014; Wang et al., 2016).

Study sites were located in an alpine meadow at Kaka Mountain (Fig. 1), which is a representative landscape in this region. Given the soil spatial heterogeneity in the area, three adjacent sites, approximately $100 \mathrm{~m}$ apart (centered at $32^{\circ} 59^{\prime} \mathrm{N}, 103^{\circ} 40^{\prime} \mathrm{E}$ ) were randomly selected. One site is located at the upper part ( $3984 \mathrm{~m}$ a.s.l.) of the alpine meadow, 


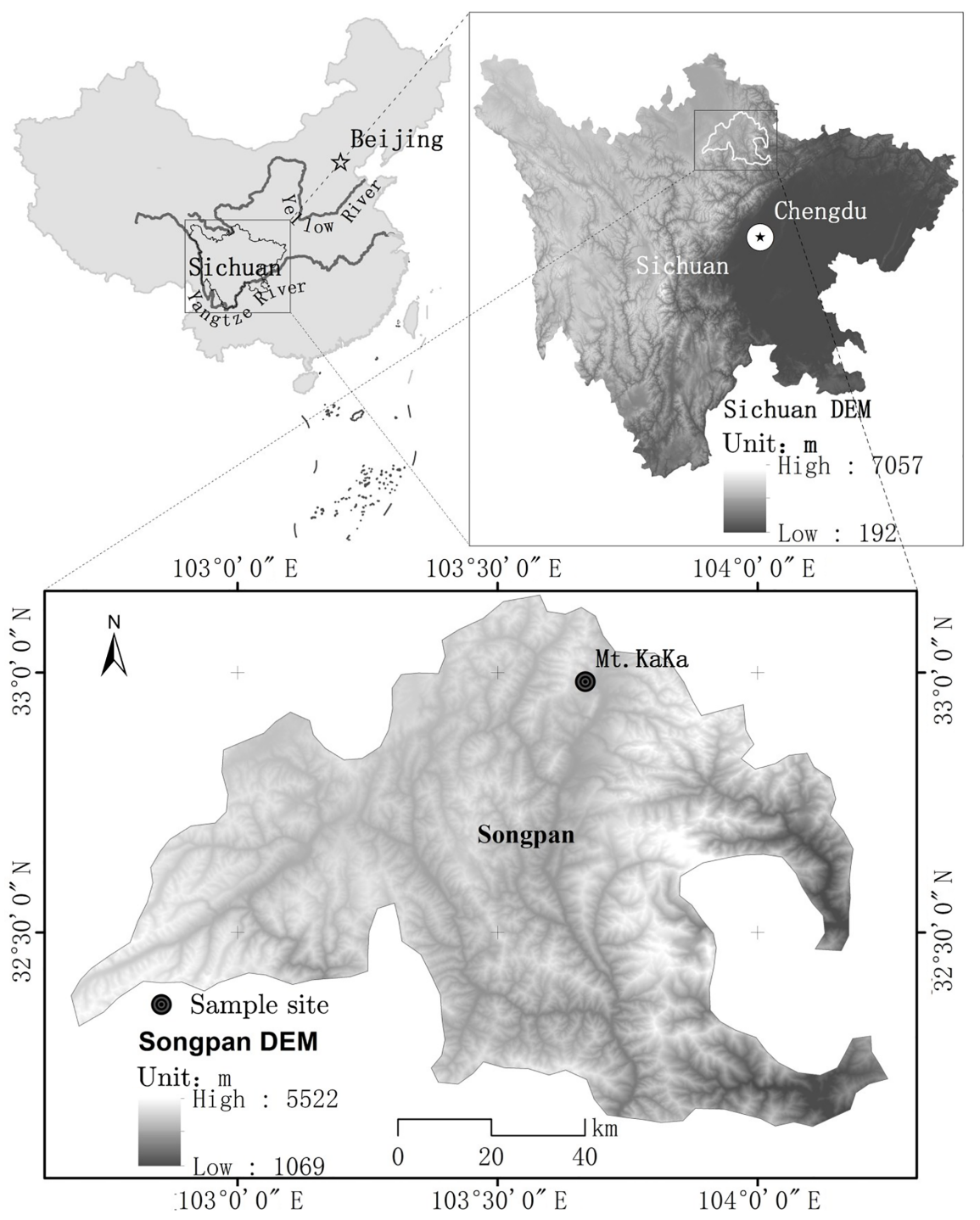

Figure 1. Location of the study site.

one at the middle part ( $3980 \mathrm{~m}$ a.s.1.), and one at the lower part (3975 m a.s.l.). Five replicates were randomly collected from each site. The samples collected from the three sites $(n=15)$ at each sampling time were used for the statistical analyses. Given that plant roots are mainly distributed at 0 $20 \mathrm{~cm}$ soil depth, soil sampling was only focused on this soil layer.

\subsection{Soil sampling}

Soil samples were collected on the 15th day of each month from April 2011 to October 2013. Overall, sampling was performed 31 times. The $1-2 \mathrm{~cm}$ layer of the surface material (i.e., O horizon, living plant roots and litter) of each soil sample was removed. During the cold periods (i.e., November to April), the samples were collected with a portable permafrost drill. The frozen soil samples were cut into small pieces $\left(<1 \mathrm{~cm}^{3}\right)$ with a knife and hammer, and large roots and sticks were removed. The soil samples collected during the warm seasons (i.e., May to October) were sieved to separate the plant materials and other fragments greater than $2 \mathrm{~mm}$ in diameter. The soil samples were then mixed and divided into three subsamples for further analysis. All the samples were processed at the laboratory of Chengdu Institute of Biology, Chinese Academy of Sciences, within 2 days of sampling.

\subsection{Soil temperature measurement}

Soil temperatures were measured at the center of each sampled location. Soil temperatures at $10 \mathrm{~cm}$ depth were recorded with DS1921G Thermochron iButton data loggers (DS1921G-F5, Maxim Integrated Products, Dallas Semiconductor Inc., Sunnyvale, CA, USA) at $1 \mathrm{~h}$ interval during the 
experimental period. Three iButton data loggers were placed at each site, and mean daily temperatures were then calculated from the data of the nine loggers. The mean temperature of the growing season was calculated by the mean daily temperatures from 1 May to 31 October, and that of the nongrowing season was calculated by the mean daily temperatures from 1 November to 30 April.

\subsection{Soil water content and nutrient analyses}

One subsample was used to measure gravimetric soil water content (SWC) after drying at $105^{\circ} \mathrm{C}$ for $12 \mathrm{~h}$. For the determination of total dissolved $\mathrm{N}$ (TDN) content, fresh soil subsamples $(15 \mathrm{~g})$ were measured into a beaker, and $\mathrm{K}_{2} \mathrm{SO}_{4}$ $(0.5 \mathrm{M})$ was then added into the soil samples with a soilweight-to-extractant volume $(w / v)$ ratio of $1: 5$. The mixture was shaken for $1 \mathrm{~h}$ at $24^{\circ} \mathrm{C}$. The extracted solution was filtered through filter paper $(0.45 \mu \mathrm{m})$ and stored at $-20^{\circ} \mathrm{C}$ before determination (Lu, 2000; Jones and Willett, 2006). Then, $10 \mathrm{~mL}$ of the extracted solution was transferred to a test tube containing $10 \mathrm{~mL}$ of oxidant $\left(\mathrm{NaOH}-\mathrm{K}_{2} \mathrm{~S}_{2} \mathrm{O}_{8}\right.$ mixed solution). The resulting solution was subjected to water bath treatment at $120^{\circ} \mathrm{C}$ for $1 \mathrm{~h}$. The TDN was then determined with an ultraviolet spectrophotometer $(\mathrm{Lu}, 2000)$. The $\mathrm{NH}_{4}^{+}-$ $\mathrm{N}$ and $\mathrm{NO}_{3}^{-}-\mathrm{N}$ contents were determined via indophenol blue colorimetry (Sah, 1994) and ultraviolet spectrophotometry (Norman et al., 1985), respectively. Dissolved organic N (DON) was calculated by subtracting dissolved inorganic $\mathrm{N}$ $\left(\mathrm{NH}_{4}^{+}-\mathrm{N}\right.$ and $\left.\mathrm{NO}_{3}^{-}-\mathrm{N}\right)$ from TDN.

For the determination of the soil dissolved organic carbon (DOC), $10 \mathrm{~g}$ of fresh soil subsamples were shaken with $0.5 \mathrm{M}$ $\mathrm{K}_{2} \mathrm{SO}_{4}$ at a $1: 5 \mathrm{w} / v$ ratio for $1 \mathrm{~h}$ at $24^{\circ} \mathrm{C}$, and the suspension was filtered at $0.45 \mu \mathrm{m}$ under suction. The DOC values of the extracts were then measured through ultraviolet spectrophotometry (Lu, 2000; Jones and Willett, 2006).

\subsection{Soil microbial biomass and community analyses}

For the determination of soil microbial biomass C (MBC) and $\mathrm{N}(\mathrm{MBN})$, fresh soil subsamples $(15 \mathrm{~g})$ were measured into a beaker and placed into a sealed vacuum dryer along with another beaker containing $100 \mathrm{~mL}$ of chloroform. The samples were then subjected to vacuum treatment three times. A vacuum dryer was placed into the incubator under a temperature of $24^{\circ} \mathrm{C}$ for $24 \mathrm{~h}$ and then subjected to vacuum treatment for approximately $30 \mathrm{~min} . \mathrm{K}_{2} \mathrm{SO}_{4}(0.5 \mathrm{M})$ was added into the chloroform-treated soil samples with a soil-weight-to-extractant volume $(w / v)$ ratio of $1: 5$. The mixture was shaken for $1 \mathrm{~h}$ at $24^{\circ} \mathrm{C}$. The extracted solution was filtered through filter paper $(0.45 \mu \mathrm{m})$ and stored at $-20^{\circ} \mathrm{C}$ before determination ( $\mathrm{Lu}, 2000$; Jones and Willett, 2006). The extracted solution of non-chloroform-treated samples was made similar to that of chloroform-treated samples, except that it was not subjected to chloroform fumigation. The contents of $\mathrm{C}$ and $\mathrm{N}$ in the extracted solution were then measured through ultraviolet spectrophotometry (Lu, 2000; Jones and Willett, 2006). The MBC and MBN were then calculated by subtracting the $\mathrm{C}$ and $\mathrm{N}$ contents of non-chloroform-treated samples from that of chloroformtreated samples, respectively. Correction factors of 0.45 for $\mathrm{C}$ and 0.54 for $\mathrm{N}$ were used to convert the chloroform labile $\mathrm{C}$ and $\mathrm{N}$ to microbial $\mathrm{C}$ and $\mathrm{N}$, respectively (Brookes et al., 1985; Lin, 2010; Wang et al., 2016).

The total colony-forming units (CFUs) of bacteria, fungi, and actinomycetes were determined via the dilution-plate method (Li, 1996; Igbinosa, 2015). A total of $10 \mathrm{~g}$ of measured fresh soil subsamples was placed into a sterile jar, to which $90 \mathrm{~mL}$ of sterile distilled water was added. The jar was then covered with a sterile rubber plug and oscillated for $10 \mathrm{~min}$ for stock solution preparation. Serial diluent was made from the stock solution. The $10^{-5}$ and $10^{-6}$ dilution ratios of the serial diluent were selected for the determination of bacteria and actinomycetes, and $10^{-2}$ and $10^{-3}$ dilution ratios for fungi determination $(\mathrm{Li}, 1996)$. The selective mediums for bacteria, fungi, and actinomycetes were beef extract peptone agar, Sabouraud dextrose agar, and Gause's synthetic agar medium, respectively (Li, 1996; Igbinosa, 2015). Soil diluent $(1 \mathrm{~mL})$ and medium $(10 \mathrm{~mL})$ at $45-50^{\circ} \mathrm{C}$ were injected into the plates and cultured at $28^{\circ} \mathrm{C}$ for $7-10$ days for the bacteria and actinomycetes. Another medium with same components was prepared at $25^{\circ} \mathrm{C}$ for $3-5$ days for the fungi. The CFUs of different microbes were counted under a microscope (Li, 1996).

\subsection{Statistical analyses}

The normal distribution and homogeneity of variance of the sample datum were analyzed with SAS 9.2 software (SAS Institute Inc., 2008). The results met the basic requirements of analysis of variance. Microbial and nutrient variables were analyzed for the testing of the intra-annual differences between the growing season (i.e., data from May to October were used as a sample set; $n=90$ ) and nongrowing season (i.e., data from November to April were used as a sample set; $n=90$ ). Their interannual differences were also tested. For the repeat measure analysis with time-dependent covariate, two-way ANOVA was performed via a mixed-effects model, with season and year specified as fixed effects, and the sample ID of each sampling time specified as the random effect. For the analysis of the microbial community shifts during the transition between nongrowing and growing seasons, differences in the number of bacteria, fungi, and actinomycetes between the late nongrowing season (i.e., in March) and early growing season (i.e., in May) were determined via two-way ANOVA. This procedure was performed for 2 years (2012 and 2013), and the specified season and year were used as fixed effects. Then, we performed Pearson correlation analysis to analyze the correlation between MBC and SWC and that between $\mathrm{MBC}$ and $\mathrm{DOC}$ during the nongrowing and growing seasons. Significant results were determined at the 
Table 1. Results from two-way ANOVA comparing growing season (May to October) and nongrowing season (November to April) values across 3 years of study for $\mathrm{SWC}, \mathrm{MBC}, \mathrm{MBN}, \mathrm{DOC}, \mathrm{NH} 4^{+}-\mathrm{N}$, $\mathrm{NO}_{3}^{-}-\mathrm{N}$, and DON in the alpine meadow.

\begin{tabular}{llrrr}
\hline Variable & Source & df & $F$ & $p$ \\
\hline SWC & year & 2 & 6.79 & 0.00 \\
& season & 1 & 180.62 & 0.00 \\
& year $\times$ season & 2 & 18.29 & 0.00 \\
\hline MBC & year & 2 & 4.46 & 0.01 \\
& season & 1 & 860.28 & 0.00 \\
& year $\times$ season & 2 & 61.67 & 0.00 \\
\hline $\mathrm{MBN}$ & year & 2 & 11.06 & 0.00 \\
& season & 1 & 0.06 & 0.80 \\
& year $\times$ season & 2 & 20.79 & 0.00 \\
\hline $\mathrm{DOC}$ & year & 2 & 5.50 & 0.01 \\
& season & 1 & 0.04 & 0.85 \\
& year $\times$ season & 2 & 14.73 & 0.00 \\
\hline $\mathrm{NH}_{4}^{+}-\mathrm{N}$ & year & 2 & 3.20 & 0.04 \\
& season & 1 & 28.3 & 0.00 \\
& year $\times$ season & 2 & 0.39 & 0.53 \\
\hline $\mathrm{NO}_{3}^{-}-\mathrm{N}$ & year & 2 & 3.28 & 0.04 \\
& season & 1 & 4.34 & 0.04 \\
& year $\times$ season & 2 & 0.18 & 0.67 \\
\hline $\mathrm{DON}^{\mathrm{N}}$ & year & 2 & 10.13 & 0.00 \\
& season & 1 & 0.63 & 0.43 \\
& year $\times$ season & 2 & 6.40 & 0.01 \\
\hline
\end{tabular}

$p<0.05$ level, and Duncan's test was performed to analyze the significant results of the multiple comparisons of the interaction effects between season and year (SAS Institute Inc., 2008).

\section{Results}

\subsection{Soil temperature and water content}

In the alpine meadow, the mean soil temperatures (at $10 \mathrm{~cm}$ depth) were $6.01,7.61$, and $7.06^{\circ} \mathrm{C}$ during the three growing seasons (May to October) from 2011 to 2013 and -1.76 and $-2.17^{\circ} \mathrm{C}$ during the two nongrowing seasons (November to April, Fig. 2). In addition, the soil was frozen (below $0{ }^{\circ} \mathrm{C}$ ) for 125 days in 2011-2012 and 165 days in 2012-2013. The soil was deeply frozen (below $-5^{\circ} \mathrm{C}$ ) for 32 days in $2011-$ 2012 and 36 days in 2012-2013. Significant seasonal and interannual differences in topsoil water contents $(0-20 \mathrm{~cm}$ depth, SWC) were observed (Table 1). The SWC showed a decreasing trend during the growing season and increasing trend during the nongrowing season (Fig. 3a), and SWC in the nongrowing season was significantly higher than that in the growing season (Fig. 3b). No significant difference was
Table 2. Pearson correlations of MBC between SWC and DOC during growing and nongrowing seasons.

\begin{tabular}{lrr}
\hline MBC & SWC & DOC \\
\hline Growing season & $0.62 * *$ & $0.64 * *$ \\
Non-growing season & $0.35 * *$ & $0.12 \mathrm{~ns}$ \\
\hline
\end{tabular}

Note: ns, no significant difference; $* *, p<0.01$.

observed between the SWC mean values in the nongrowing season of 2011-2012 $(64.73 \% \pm 2.22 \%)$ and those in the nongrowing season of 2012-2013 $(65.68 \% \pm 4.03 \% ; p>$ 0.05; Fig. 3b). However, the SWC mean values in the growing seasons of 2011-2013 were significantly different ( $p<$ 0.05 ; Fig. $3 \mathrm{~b}$ ), and the lowest SWC was $46.43 \% \pm 2.28 \%$ in 2012-2013.

\subsection{Soil microbial biomass and community}

Significant differences in MBC between seasons $(F=$ $860.28, \mathrm{df}=1, p=0.00)$ and years $(F=4.46, \mathrm{df}=2 ; p=$ 0.01 ) were observed in the soils of the alpine meadow (Table 1). The annual peak of MBC occurred in the late nongrowing season (March) but eventually decreased sharply, indicating a diminishing trend during the growing season. The MBC reached a minimum value in the late growing season (September) and then showed an increasing trend during the nongrowing season (Fig. 4a). However, a trend of significant decrease in MBC was observed in February when the soil temperatures were the lowest (below $-5^{\circ} \mathrm{C}$ ). In addition, the mean $\mathrm{MBC}$ value during the nongrowing season in 2012-2013 (i.e., $943.93 \mathrm{mg} \mathrm{kg}^{-1} \pm 80.01 \mathrm{mg} \mathrm{kg}^{-1}$ ) was significantly $(p<0.05)$ higher than those in the other seasons. Meanwhile, the mean MBC value during the growing season in $2012-2013$ (i.e., $143.53 \mathrm{mg} \mathrm{kg}^{-1} \pm 20.99 \mathrm{mg} \mathrm{kg}^{-1}$ ) was the lowest (Fig. 4c). The MBC during the growing season had highly significant positive correlation with SWC $(p<0.01$, $r=0.62$; Table 2).

The soil MBN values had significant interannual differences $(F=11.06, \mathrm{df}=2 ; p=0.00)$, but the seasonal differences among MBN values were nonsignificant $(F=0.06$, $\mathrm{df}=1 ; p=0.80$; Table 1$)$. The seasonal and interannual dynamics of MBN were similar to those of MBC, and its annual peak generally occurred in April or May. Furthermore, no significant difference was observed between the mean MBN values in the growing season of 2013 and those in 2011-2012 $(p>0.05)$. The lowest MBN value (72.06 $\mathrm{mg} \mathrm{kg}^{-1} \pm 5.93 \mathrm{mg} \mathrm{kg}^{-1}$ ) was observed during the growing season in 2012-2013 (Fig. 4c).

Additionally, the microbial community comprised bacteria, fungi, and actinomycetes, showing a significant shift during the winter-spring transition (March to May; $p<0.05$; Fig. 5). The number of bacteria in May was significantly higher $(p<0.05)$ than that in March, and the num- 


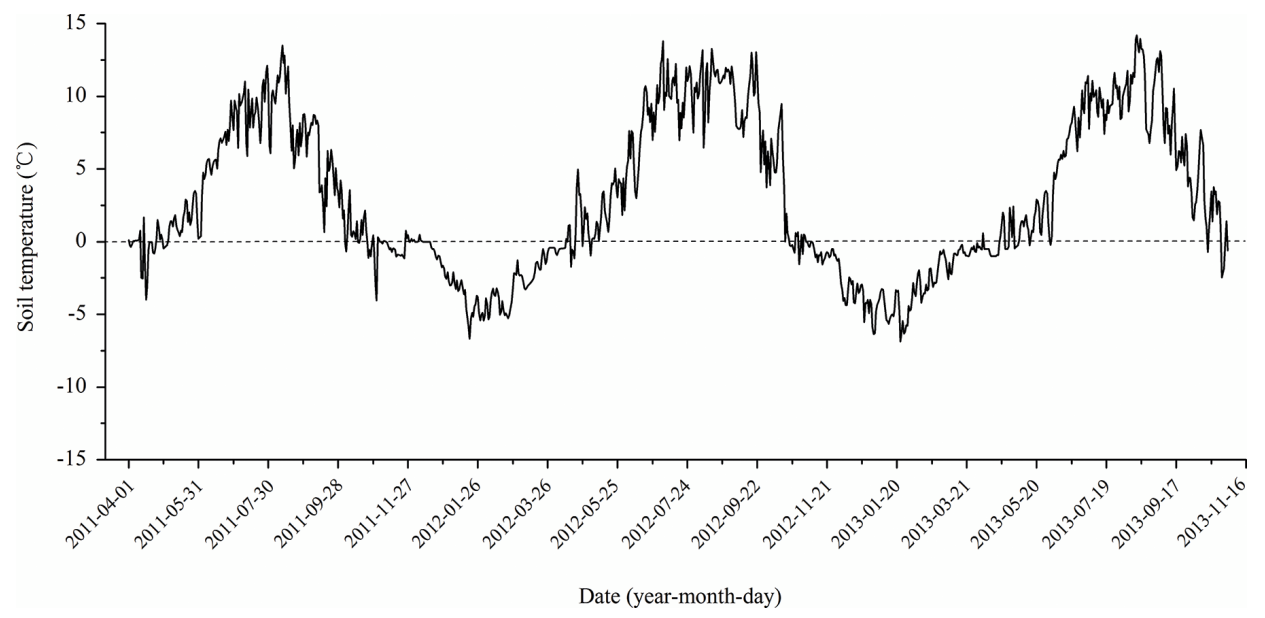

Figure 2. Mean daily soil temperature in the alpine meadow from April 2011 to October 2013. Thermochron iButton data loggers were placed at $10 \mathrm{~cm}$ soil depth to obtain automatic readings every $1 \mathrm{~h}$, and the mean daily soil temperature was calculated every day.
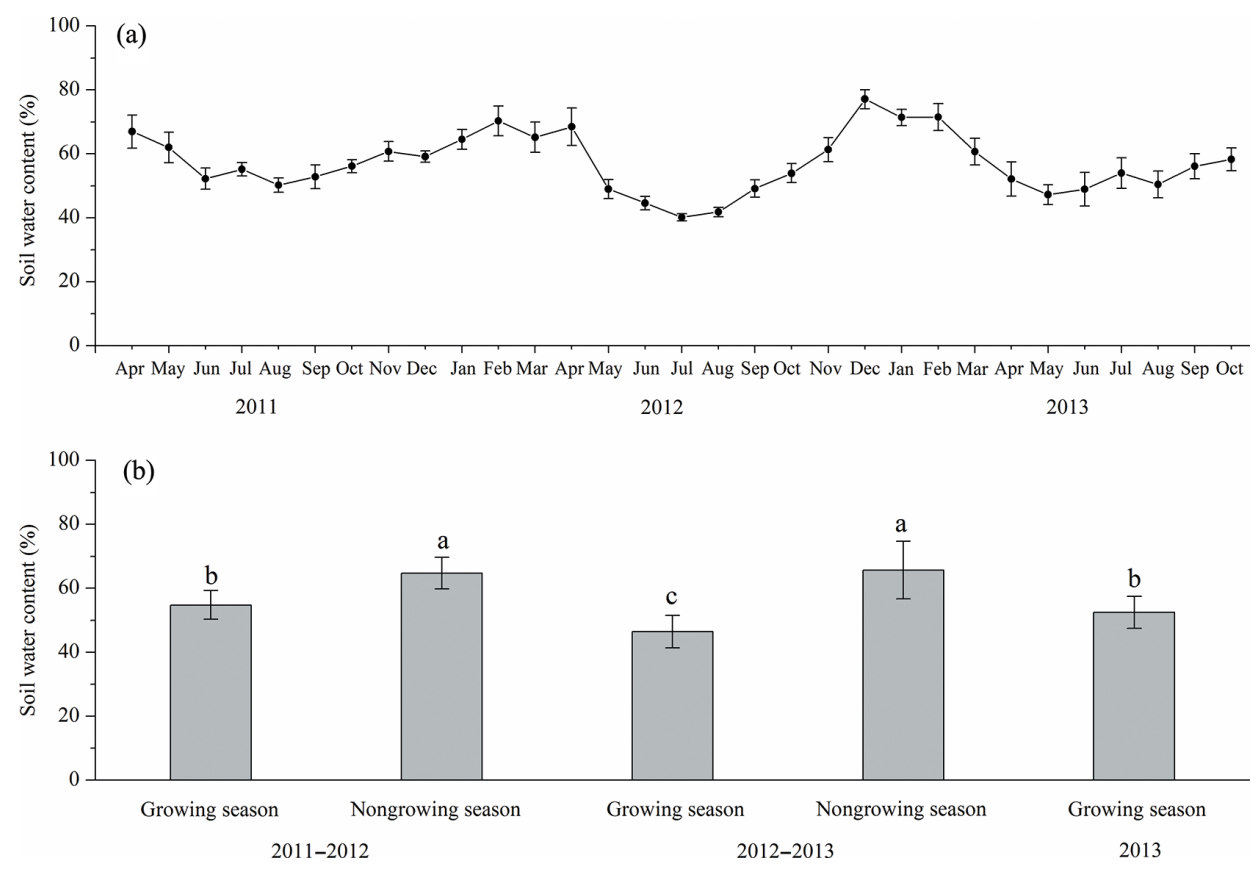

Figure 3. Dynamics of soil water content (a; mean $\pm \mathrm{SE} ; n=15)$ and its seasonal and interannual differences $(\mathbf{b} ;$ mean $\pm \mathrm{SE} ; n=90)$ from 2011 to 2013.

ber of bacteria in May 2013 (i.e., $8.25 \times 10^{6} \mathrm{CFU} \mathrm{g}^{-1}$ ) was significantly higher $(p<0.05)$ than that in 2012 (i.e., $\left.7.22 \times 10^{6} \mathrm{CFU} \mathrm{g}^{-1}\right)$. The numbers of fungi and actinomycetes in March were significantly higher than that in May $(p<0.05)$. The number of fungi in March 2013 $\left(4.33 \times 10^{4} \mathrm{CFU} \mathrm{g}^{-1}\right)$ was the highest, and no significant difference was observed between the number of actinomycetes in March 2012 and that in March 2013 ( $p>0.05$; Fig. 5).

\subsection{Soil dissolved organic carbon}

Significant interannual differences $(F=5.50, \mathrm{df}=2 ; p=$ $0.01)$ in soil DOC contents were observed, and the seasonal dynamics of DOC had no significant difference $(F=0.04$, $\mathrm{df}=1 ; p=0.85$; Table 1$)$. DOC peaks annually in May and shows a diminishing trend during the growing season and increasing trend during the nongrowing season (Fig. 6a). The DOC contents during the nongrowing season in 2011-2012 $\left(174.27 \mathrm{mg} \mathrm{kg}^{-1} \pm 32.59 \mathrm{mg} \mathrm{kg}^{-1}\right)$ and growing season in 2012-2013 (170.85 $\mathrm{mg} \mathrm{kg}^{-1} \pm 41.19 \mathrm{mg} \mathrm{kg}^{-1}$ ) had no significant difference $(p>0.05)$, but were significantly lower 


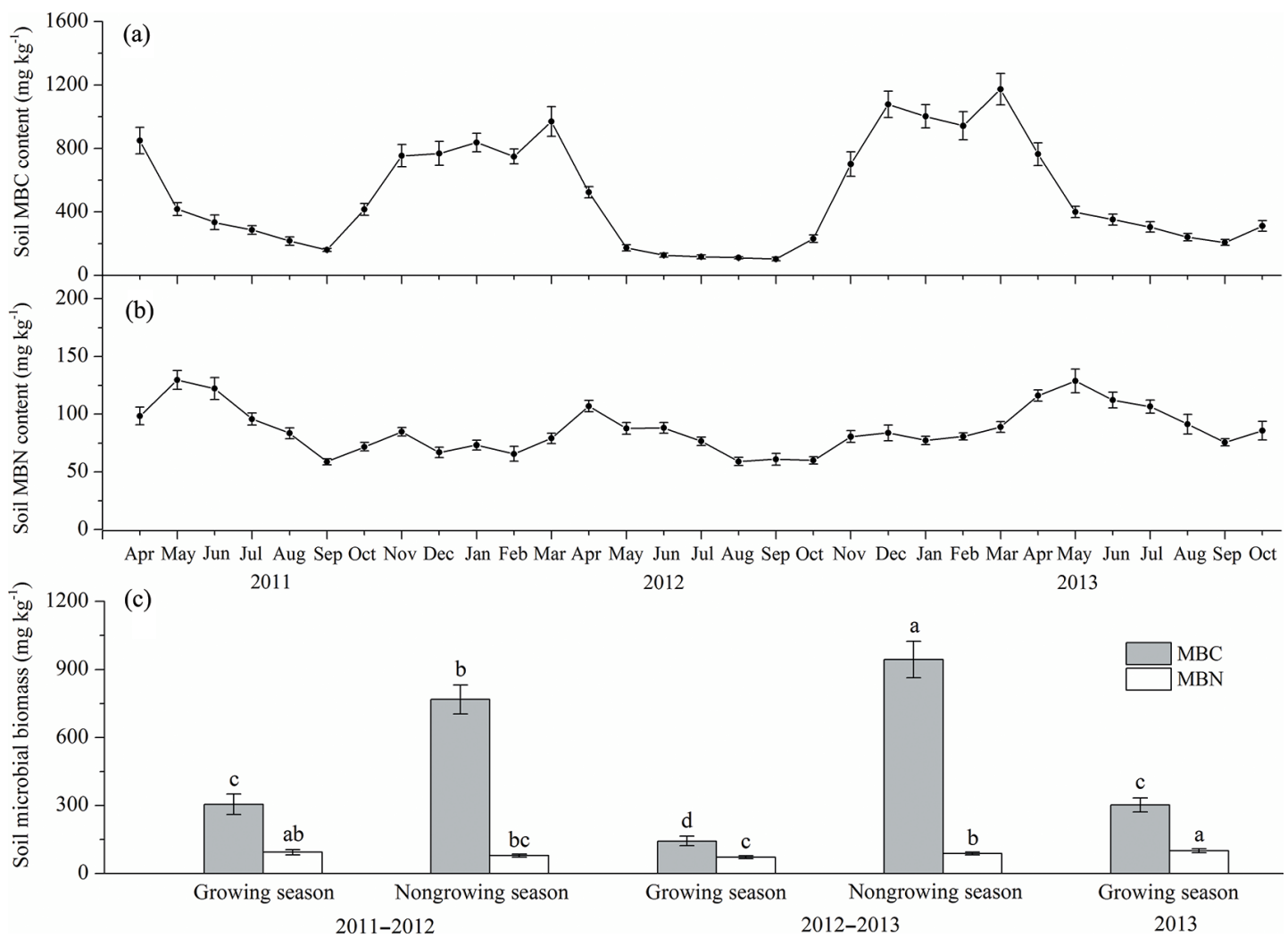

Figure 4. Dynamics of microbial biomass $\mathrm{C}$ and $\mathrm{N}(\mathbf{a}, \mathbf{b} ;$ mean $\pm \mathrm{SE} ; n=15)$, and their seasonal and interannual differences (c; mean $\pm \mathrm{SE}$; $n=90$ ) from April 2011 to October 2013 (mean \pm SE; $n=90$ ). The sampling time was on the 15 th day of each month during the growing season from May to October, and during the nongrowing season from November to April of the following year. Seasons and years were compared using two-way ANOVA, and different lowercase letters indicate significant differences of the interaction effects between season and year determined via Duncan's test $(p<0.05)$.

than those in other seasons ( $p<0.05$; Fig. 6b). Furthermore, the DOC during the growing season had highly significant positive correlation with MBC ( $p<0.01, r=0.64$; Table 2$)$.

\subsection{Soil-available nitrogen}

Soil ammonium $\mathrm{N}\left(\mathrm{NH}_{4}^{+}-\mathrm{N}\right)$ contents showed significant seasonal and interannual differences $(F=28.3, \mathrm{df}=1 ; p=$ 0.00 ; and $F=3.20, \mathrm{df}=2 ; p=0.04$; Table 1$)$. The annual peak of the $\mathrm{NH}_{4}^{+}-\mathrm{N}$ content occurred in the late nongrowing season (April) and then sharply declined during the early growing season before finally showing an increasing trend during the nongrowing season (Fig. 7a). The $\mathrm{NH}_{4}^{+}-\mathrm{N}$ content in the nongrowing season was significantly higher $(p<0.05)$ than that in the growing season. The $\mathrm{NH}_{4}^{+}-$ $\mathrm{N}$ content during the nongrowing season in 2012-2013 ( $22.21 \mathrm{mg} \mathrm{kg}^{-1} \pm 3.87 \mathrm{mg} \mathrm{kg}^{-1}$ ) was significantly higher than that in $2011-2012\left(17.23 \mathrm{mg} \mathrm{kg}^{-1} \pm 3.85 \mathrm{mg} \mathrm{kg}^{-1}\right)$, and no significant difference was observed among the $\mathrm{NH}_{4}^{+}-\mathrm{N}$ content during the growing seasons in 2011-2013 ( $p>0.05$; Fig. 8).

Significant seasonal and interannual differences in soil nitrate $\mathrm{N}\left(\mathrm{NO}_{3}^{-}-\mathrm{N}\right)$ contents were observed $(F=4.34, \mathrm{df}=1$; $p=0.04 ;$ and $F=3.28, \mathrm{df}=2 ; p=0.04$; Table 1$).$ The $\mathrm{NO}_{3}^{-}-\mathrm{N}$ content showed an increasing trend during nongrowing seasons and increased initially before decreasing during the growing seasons (Fig. 7b). Furthermore, a decreasing trend in $\mathrm{NO}_{3}^{-}-\mathrm{N}$ content was observed during the soil-thawing period (April to May). The $\mathrm{NO}_{3}^{-}-\mathrm{N}$ contents peaked annually in June while that during the nongrowing season in $2011-2012\left(7.64 \mathrm{mg} \mathrm{kg}^{-1} \pm 1.12 \mathrm{mg} \mathrm{kg}^{-1}\right)$ was the lowest. No significant difference was observed among the $\mathrm{NO}_{3}^{-}-\mathrm{N}$ contents of the other seasons ( $p>0.05$; Fig. 8).

The DON contents had significant interannual differences $(F=10.13, \mathrm{df}=2 ; p=0.00)$, but their seasonal differences were nonsignificant $(F=0.63, \mathrm{df}=1 ; p=0.43$; Table 1). In general, the peak DON content was observed in April or May, then sharply decreased during the middle and late growing season, and finally increased during the nongrowing season (Fig. 7c). Furthermore, the mean DON value during the growing season in 2012-2013 $\left(7.53 \mathrm{mg} \mathrm{kg}^{-1} \pm 1.74 \mathrm{mg} \mathrm{kg}^{-1}\right)$ was the lowest, and it was significantly lower than those in the other years $(p<0.05$; Fig. 8). 


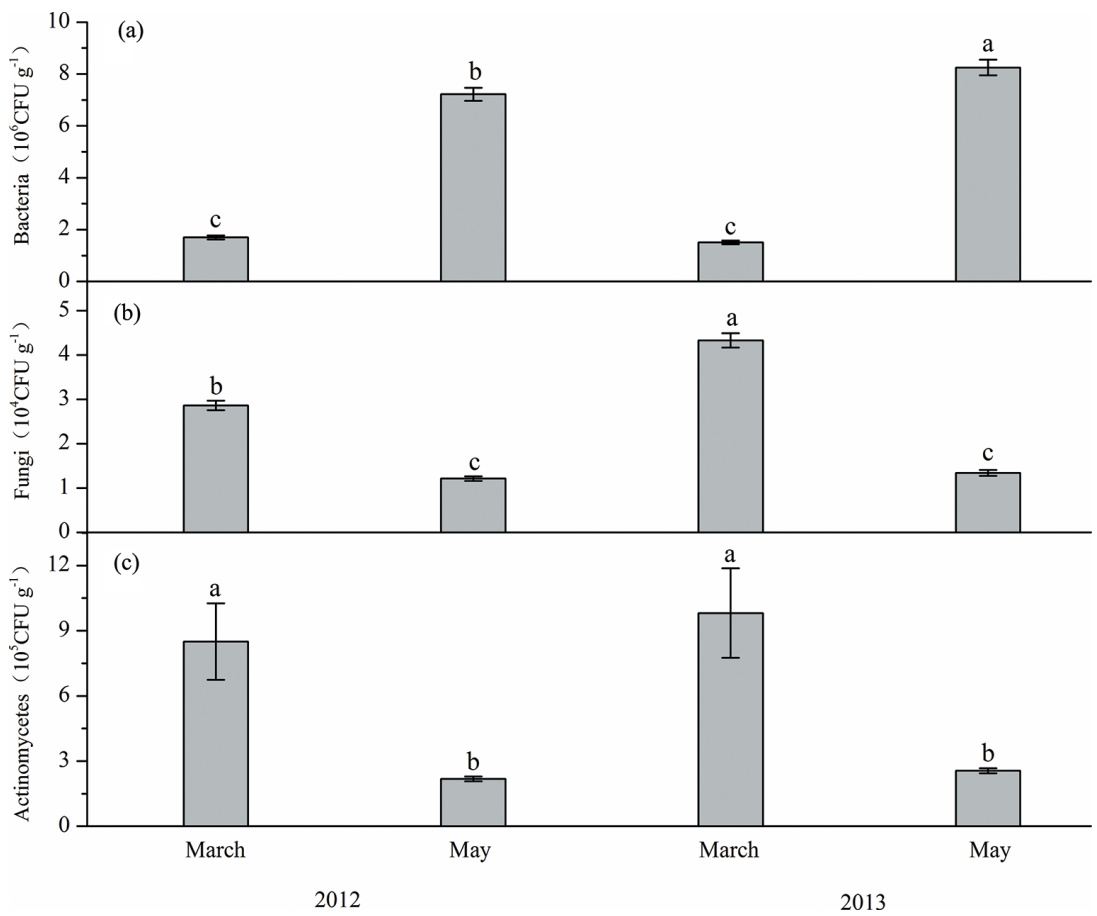

Figure 5. Changes in the number of bacteria (a), fungi (b), and actinomycetes (c) during the transition between freezing and thawing periods (mean $\pm \mathrm{SE} ; n=15$ ). The sampling time each year during the freezing period was on 15 March and during the thawing period was on $15 \mathrm{May}$. Different lowercase letters indicate significant differences of the interaction effects between season and year according to two-way ANOVA $(p<0.05)$.
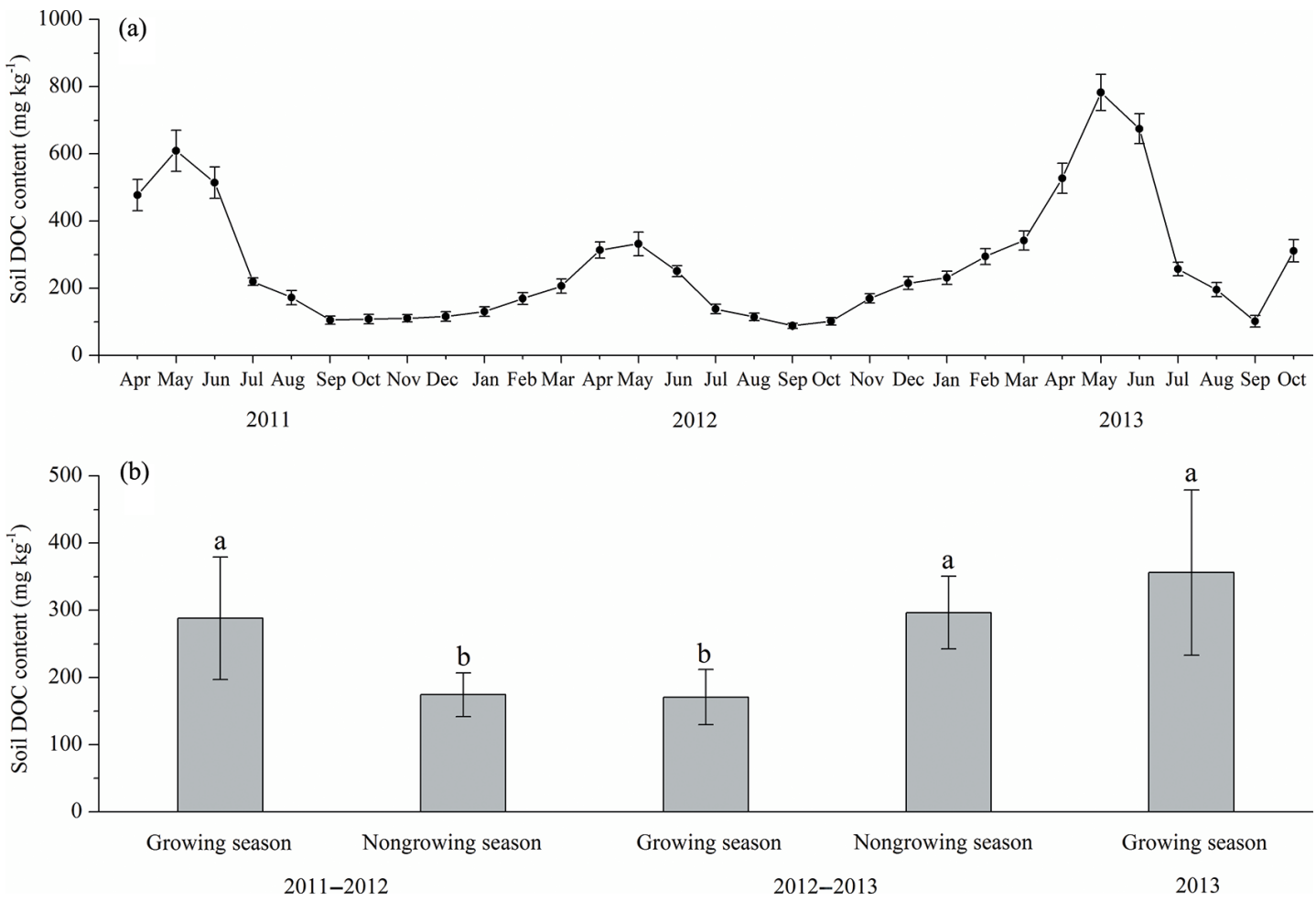

Figure 6. Dynamics of dissolved organic $\mathrm{C}(\mathbf{a} ;$ mean $\pm \mathrm{SE} ; n=15)$ and its seasonal and interannual differences $(\mathbf{b} ;$ mean $\pm \mathrm{SE} ; n=90)$ from 2011 to 2013. 


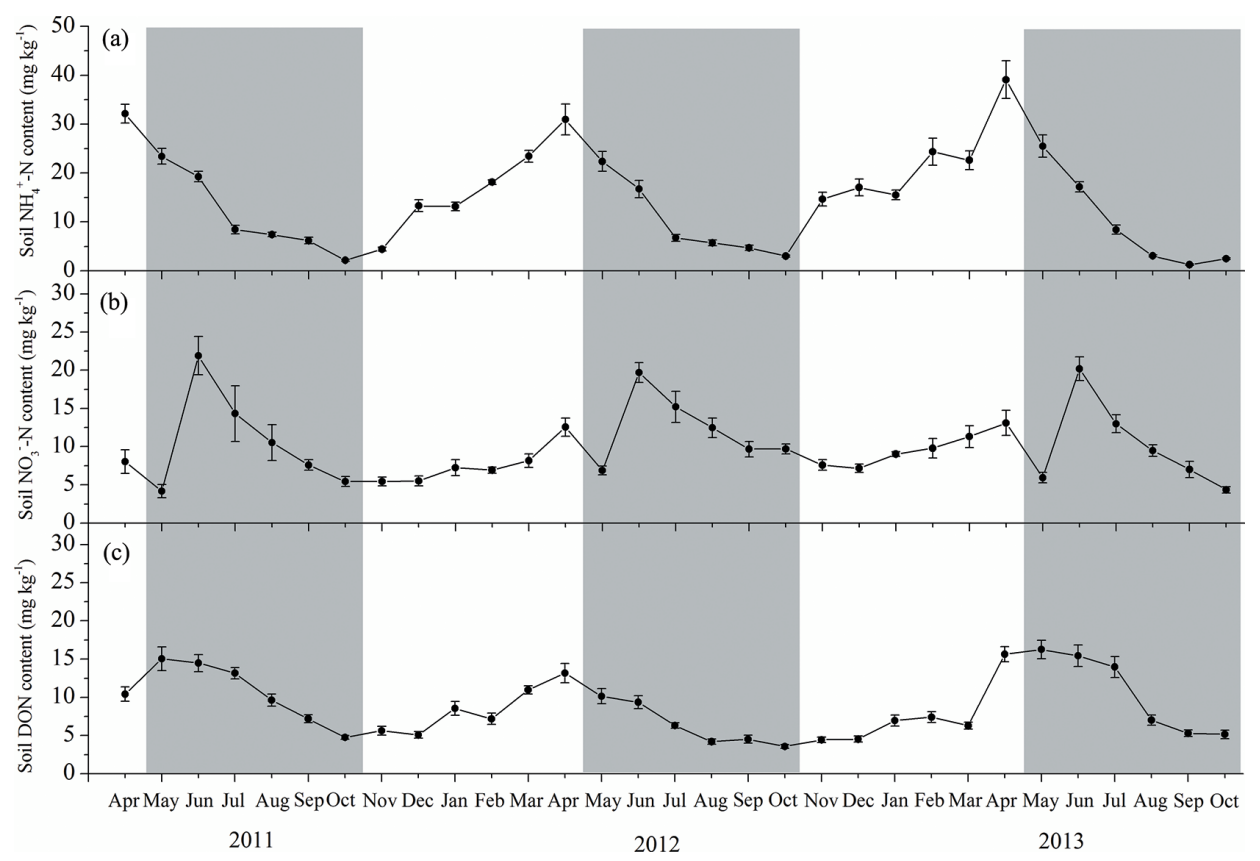

Figure 7. Dynamics of $\mathrm{NH}_{4}^{+}-\mathrm{N}(\mathbf{a}), \mathrm{NO}_{3}^{-}-\mathrm{N}(\mathbf{b})$, and DON (c) in soils of the alpine meadow from April 2011 to October 2013 (mean $\pm \mathrm{SE}$; $n=15)$.

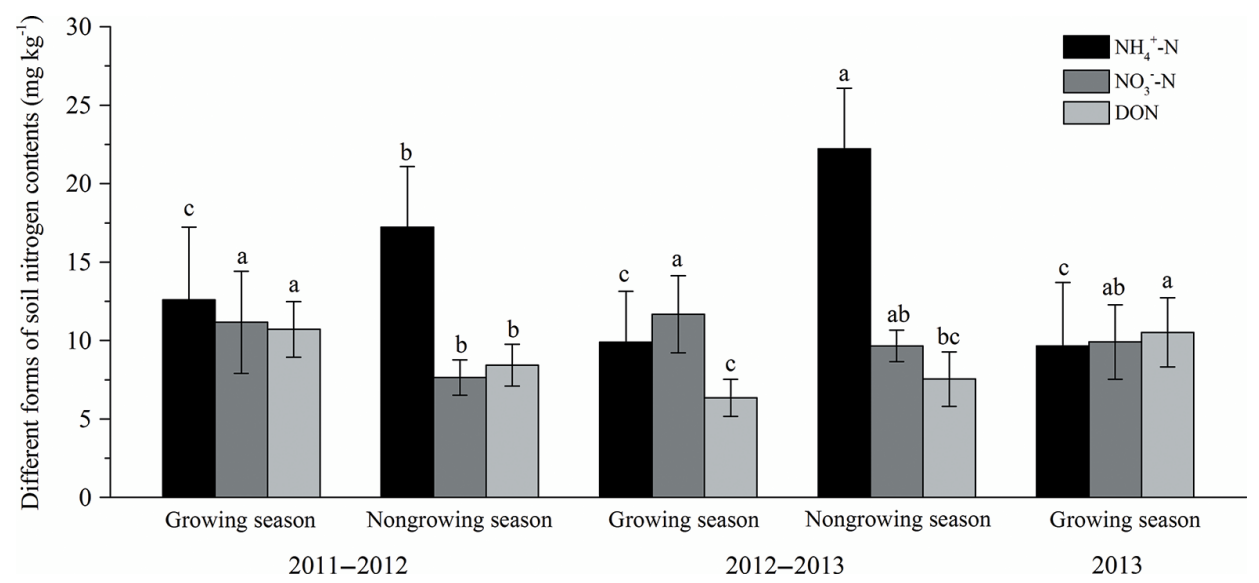

Figure 8. Changes in $\mathrm{NH}_{4}^{+}-\mathrm{N}, \mathrm{NO}_{3}^{-}-\mathrm{N}$, and DON of growing and nongrowing seasons from 2011 to 2013 (mean $\pm \mathrm{SE} ; n=90$ ). The sampling time was on the 15th day of each month from May to October during the growing season and during the nongrowing season from November to April of the following year. Seasonal and interannual differences were compared using two-way ANOVA. Different lowercase letters indicate significant differences of the interaction effects between season and year determined via Duncan's test $(p<0.05)$.

\section{Discussion}

\subsection{Seasonal microbial biomass and available nitrogen dynamics}

The significant seasonal dynamics of the soil microbial biomass and available $\mathrm{N}$ pools were observed in the alpine meadow located in the eastern part of the Qinghai-Tibet Plateau for 3 years (Table 1; Figs. 4 and 7). Generally, the soil $\mathrm{MBC}$ and available $\mathrm{N}$ pools both increased at the beginning of the early nongrowing season, and this finding is consistent with the results of previous studies conducted in other Arctic and alpine ecosystems (Brooks et al., 1998; Lipson et al., 1999, 2002; Edwards et al., 2006; Larsen et al., 2007; Buckeridge et al., 2010; Edwards and Jefferies, 2013). This period of active microbial activity and $\mathrm{N}$ mineralization might benefit from substrates conducive to microbial growth, particularly those supplied by the fresh plant litter inputs in autumn (Lipson et al., 1999; Nemergut et al., 2005). However, a decline in soil MBC was observed during the deeply cold period (i.e., in February when soil temperatures were below 
$-5^{\circ} \mathrm{C}$ ). This decline implied that the temperature threshold of the survival of these cold-adapted microbial communities was at lowest $-5^{\circ} \mathrm{C}$.

The annual peak of MBC generally occurred during the late nongrowing season while the mean soil temperatures were below $0^{\circ} \mathrm{C}$. A modest reduction in $\mathrm{MBC}$ was observed at the onset of early soil thaw, and a steep decline in MBC occurred during the late soil-thawing period when the mean soil temperatures exceeded $0^{\circ} \mathrm{C}$. This sharp decrease in MBC during the transition between nongrowing and growing seasons was similar to the changes of MBC in other Arctic and alpine meadows during late winter and early spring (Lipson et al., 2002; Edwards et al., 2006). Previous studies suggested several factors that contribute to the decline of MBC during the soil-thawing period. First, physical changes in soil during thawing can result in microbial cell death and release of solutes (Jefferies et al., 2010; Edwards and Jefferies, 2013). Second, depletion of soil-available $C$ and $N$ can also lead to microbial reductions during soil thawing (Edwards et al., 2006; Buckeridge and Grogan, 2008). Furthermore, Edwards and Jefferies (2013) hypothesized that oxygen availability in soil may lead to MBC reductions because aerobic microbial growth can still be supported in winter. Anaerobic soil conditions are established as soils become flooded with liquid water during the late soil thaw. However, in our study, increases in DOC and inorganic $\mathrm{N}\left(\mathrm{NH}_{4}^{+}-\mathrm{N}\right.$ and $\mathrm{NO}_{3}^{-}-\mathrm{N}$ ) contents was observed during the nongrowing season, implying that available $\mathrm{C}$ and $\mathrm{N}$ were relatively sufficient and might not have restricted microbial activity during the winter-spring transition. This phenomenon may be closely related to the high plant community productivity in the eastern part of the Qinghai-Tibet Plateau. The aboveground biomass ranges from 299.8 to $475.8 \mathrm{~g} \mathrm{~m}^{-2} \mathrm{yr}^{-1}$ in the alpine meadows of this region (Gao et al., 2008; Yang et al., 2014), but $198 \pm 73.8 \mathrm{~g} \mathrm{~m}^{-2} \mathrm{yr}^{-1}$ in the paramo grassland of Colombia (Hofstede et al., 1995), and ranges from 160 to $230 \mathrm{~g} \mathrm{~m}^{-2} \mathrm{yr}^{-1}$ in the alpine meadows of the central Rocky mountains (Walker et al., 1994; Körner, 2003). Furthermore, the soil organic matter content in the alpine meadows of this region ranges from 69.7 to $112.4 \mathrm{~g} \mathrm{~kg}^{-1}$ (Wu and Onipchenko, 2005), but $12.8 \mathrm{~g} \mathrm{~kg}^{-1}$ in the Alaskan tundra (Körner, 2003), and ranges from 20.3 to $34.7 \mathrm{~g} \mathrm{~kg}^{-1}$ in the alpine meadows of the Alps and Colorado (Billings and Bliss, 1959; Körner, 2003).

Additionally, a significant difference was observed between the microbial community composition in the nongrowing seasons and those in the growing seasons (Fig. 5). Winter microbial community was dominated by fungi, which is more adapted to cold temperatures and utilizes complex substrates (Lipson et al., 2002; Schadt et al., 2003). Apart from the fungi community, actinomycetes are another important microbial community in winter soil. Furthermore, the proportion of bacteria significantly increased during the early growing season after the soil was completely thawed. By contrast, the proportion of fungi and that of actinomycetes declined considerably. This shift in microbial community may lead to the sharp decline in MBC during soil thaw possibly because the $\mathrm{C}$ investment per unit volume in fungal cells was threefold that in bacteria cells (Buckeridge and Grogan, 2008).

In the present study, inorganic $\mathrm{N}$ and DON contents both showed an increasing trend during the nongrowing season, and this trend was closely related to high microbial biomass in the soils of this region (Lipson et al., 1999; Matthew Robson et al., 2010). However, divergent dynamics among different forms of available $\mathrm{N}$ were observed during the growing season (Fig. 8). An obviously increased trend of $\mathrm{NH}_{4}^{+-}$ $\mathrm{N}$ content was found during the early soil thawing. The potential reasons for this phenomenon are as follows. On the one hand, frequent and strong freeze-thaw cycles during this period may contribute to the release of unavailable $\mathrm{NH}_{4}^{+}-\mathrm{N}$ from the organic and inorganic colloids in alpine soils (Freppaz et al., 2007). On the other hand, snow melting during this period may be an important source of $\mathrm{NH}_{4}^{+}-\mathrm{N}$ (Williams and Tonnessen, 2000). At the start of the growing season, $\mathrm{NH}_{4}^{+}-\mathrm{N}$ content sharply decreased possibly because alpine meadow plants prefer $\mathrm{NH}_{4}^{+}-\mathrm{N}$ (Jaeger et al., 1999; Gherardi et al., 2013). Moreover, strong microbial activity in soil requires a large amount of $\mathrm{NH}_{4}^{+}-\mathrm{N}$ at increasing temperatures (Bowman, 1992; Schmidt and Lipson, 2004). As observed in other alpine regions (Brooks et al., 1997; Edwards et al., 2007), $\mathrm{NO}_{3}^{-}-\mathrm{N}$ content sharply declined during the soil-thawing period in our study mostly because a massive amount of $\mathrm{NO}_{3}^{-}-\mathrm{N}$ might have run off with the snowmelt. The $\mathrm{NO}_{3}^{-}-\mathrm{N}$ content first increased during the early growing season and then decreased during the middle growing season as the $\mathrm{NH}_{4}^{+}-\mathrm{N}$ content decreased. Meanwhile, DON content slightly decreased during the early and middle growing seasons and sharply decreased during the late growing season as both $\mathrm{NH}_{4}^{+}-\mathrm{N}$ and $\mathrm{NO}_{3}^{-}-\mathrm{N}$ were exhausted. These results implied that although the DON may not be the main source of $\mathrm{N}$ pools for plants, it is an effective available $\mathrm{N}$ pool supplement. Furthermore, the seasonal dynamics of different available $\mathrm{N}$ pools showed significant complementarity with the nutrient supply process.

\subsection{Interannual microbial biomass and available nitrogen dynamics}

Significant interannual differences in microbial biomass and available $\mathrm{N}$ were observed across the study years. For example, the $\mathrm{MBC}$ and $\mathrm{NH}_{4}^{+}-\mathrm{N}$ contents during the nongrowing season in 2012-2013 were significantly higher than those in 2011-2012, and the lowest MBC values during the growing season were in 2012-2013 (Figs. 4 and 8). Furthermore, significant positive correlation between $\mathrm{MBC}$ and SWC was observed during the growing season (Table 2). This result suggested that interannual variability in soil water conditions is an important environmental driver that affects microbial biomass in alpine meadows. First, low soil moisture 
in the growing season causes a decline in plant productivity (Körner, 2003), resulting in the decline of $\mathrm{C}$ substrates supplied by plant root exudates and litter. Second, low soil moisture in summer leads to increased oxidation in the surface soil, thus exerting significant influence on microbial communities (Blodau et al., 2004), and some of this influence is retained during winter (Edwards and Jefferies, 2013). Notably, the nongrowing season in 2011-2012 was warmer and drier than that in 2012-2013 and might have been accompanied by frequent freeze-thaw cycles during the early period of this season (Mellander et al., 2007; Henry, 2008). These environmental variations might contribute to the reduction in soil microbial biomass during nongrowing seasons (Larsen et al., 2002; Yanai et al., 2004; Mellander et al., 2007; Henry, 2008). Although the extent of the influence of these environmental factors on soil microbial biomass cannot be verified, our results suggested that soil moisture and temperature are two important environmental factors influencing the interannual dynamics of soil microbial biomass.

In the alpine meadow, organic matter decomposition and nutrient mineralization caused by soil microbial activity during a long cold season play a crucial role in accumulating soil inorganic N pool (Hidy, 2003; Rinnan et al., 2007), and the microorganism itself is also an important soil organic $\mathrm{N}$ pool (Lipson et al., 2002). Thus, the interannual pattern of the soil microbial biomass largely affects interannual changes in soil $\mathrm{N}$ pool. Soil $\mathrm{NH}_{4}^{+}-\mathrm{N}$ and DON showed consistent interannual variation with soil $\mathrm{MBC}$ during the nongrowing season. However, they showed a divergent interannual pattern during the growing season possibly because of plant and microbe uptake and leaching effects. Meanwhile, for $\mathrm{NO}_{3}^{-}-$ $\mathrm{N}$, relatively small interannual variability was observed. The interannual variability of precipitation affected the interannual pattern of available inorganic $\mathrm{N}$ pool in the soil. The snowmelt is not only an important supplement for the $\mathrm{NH}_{4}^{+}-$ $\mathrm{N}$ pool (Williams and Tonnessen, 2000); it is also a cause of mass $\mathrm{NO}_{3}^{-}-\mathrm{N}$ losses during soil-thawing periods (Brooks et al., 1997; Edwards et al., 2007). Therefore, such interannual variations in the microbial and nutrient dynamics may become increasingly common and pronounced in the alpine meadow in the eastern part of the Qinghai-Tibet Plateau as a result of multiple impacts of climate change, particularly increasing extreme weather events, such as winter warming and heterogeneous precipitation (Edwards and Jefferies, 2013).

\section{Conclusions}

A trend of increasing soil MBC and available $\mathrm{N}$ pools was observed in nongrowing seasons, and a sharp decline in MBC was observed during the soil-thawing period. Microbial activity may not be restricted by the soil-available $\mathrm{C}$ and $\mathrm{N}$ in the time of soil thaw. However, a shift in microbial community induced by changing temperatures may largely con- tribute to the decline of MBC. Different forms of available $\mathrm{N}$ pools showed a divergent decreasing pattern during the growing season, suggesting that a significantly complementary pattern of nutrient supply exists among different $\mathrm{N}$ pools. Furthermore, the presence of soil microorganisms is not only closely correlated with the accumulation of inorganic $\mathrm{N}$ pools; these organisms are also important soil organic $\mathrm{N}$ pools. Thus, the interannual dynamics of soil microbial biomass substantially affects the interannual differences among soil-available $\mathrm{N}$ pools. According to our results, soil temperature and water conditions are the primary environmental factors driving the seasonal and interannual dynamics of soil microbial biomass and available $\mathrm{N}$ pools. Owing to the changing climates of alpine ecosystems, soil microbial activities and nutrient supply patterns are expected to change further. These changes play an important role in the productivity and biodiversity of these regions. Long-term integrative studies on intra- and interannual variations of microbial and nutrient dynamics have important implications for ecosystem functions and their responses to environmental changes. Combined with some objective experimental studies, these research results can provide crucial insights into the biogeochemical cycles and functions of ecosystems in the eastern part of the Qinghai-Tibet Plateau, and their potential responses to future climate change.

Data availability. The data set related to this study is provided in the Supplement.

\section{The Supplement related to this article is available online at https://doi.org/10.5194/bg-15-567-2018-supplement.}

Author contributions. FS, NW, and YW designed the experiments; $\mathrm{BX}$ and JW carried field experiments out; BX prepared the manuscript with contributions from all co-authors.

Competing interests. The authors declare that they have no conflict of interest.

Acknowledgements. The study was funded by the Key Research and Development Plan of China (2016YFC0501805).

Edited by: Michael Weintraub

Reviewed by: four anonymous referees 


\section{References}

Billings, W. D. and Bliss, L. C.: An alpine snowbank environment and its effects on vegetaiton, plant development, and productivity, Ecology, 40, 388-397, 1959.

Blodau, C., Basiliko, N., and Moore, T. R.: Carbon turnover in peatland mesocosms exposed to different water table levels, Biogeochemistry, 67, 331-351, 2004.

Bowman, W. D.: Inputs and storage of nitrogen in winter snowpack in an alpine ecosystem, Arctic Alpine Res., 24, 211-215, 1992.

Brookes, P. C., Landman, A., Pruden, G., and Jenkinson, D. S.: Chloroform fumigation and the release of soil nitrogen: a rapid direct extraction method to measure microbial biomass nitrogen in soil, Soil Biol. Biochem., 17, 837-842, 1985.

Brooks, P. D., Williams, M. W., and Schmidt, S. K.: Microbial activity under alpine snowpacks, Niwot Ridge, Colorado, Biogeochemistry, 32, 93-113, 1996.

Brooks, P. D., Schmidt, S. K., and Williams, M. W.: Winter production of $\mathrm{CO}_{2}$ and $\mathrm{N}_{2} \mathrm{O}$ from Alpine tundra: Environmental controls and relationship to inter-system $\mathrm{C}$ and $\mathrm{N}$ fluxes, Oecologia, 110, 403-413, 1997.

Brooks, P. D., Williams, M. W., and Schmidt, S. K.: Inorganic nitrogen and microbial biomass dynamics before and during spring snowmelt, Biogeochemistry, 43, 1-15, 1998.

Buckeridge, K. M. and Grogan, P.: Deepened snow alters soil microbial nutrient limitations in arctic birch hummock tundra, Appl. Soil Ecol., 39, 210-222, 2008.

Buckeridge, K. M. and Grogan, P.: Deepened snow increases late thaw biogeochemical pulses in mesic low arctic tundra, Biogeochemistry, 101, 105-121, 2010.

Buckeridge, K. M., Banerjee, S., Siciliano, S. D., and Grogan, P.: The seasonal pattern of soil microbial community structure in mesic low arctic tundra, Soil Biol. Biochem., 65, 338-347, 2013.

Chinese Soil Taxonomy Research Group: Chinese Soil Taxonomy, China Agriculture Scientech Press, 1995.

Deming, J. W.: Psychrophiles and polar regions, Curr. Opin. Microbiol., 5, 301-309, 2002.

Edwards, A. C., Scalenghe, R., and Freppaz, M.: Changes in the seasonal snow cover of alpine regions and its effect on soil processes: A review, Quaternary Int., 162, 172-181, 2007.

Edwards, K. A. and Jefferies, R. L.: Inter-annual and seasonal dynamics of soil microbial biomass and nutrients in wet and dry low-Arctic sedge meadows, Soil Biol. Biochem., 57, 83-90, 2013.

Edwards, K. A., McCulloch, J., Kershaw, G. P., and Jefferies, R. L.: Soil microbial and nutrient dynamics in a wet Arctic sedge meadow in late winter and early spring, Soil Biol. Biochem., 38, 2843-2851, 2006.

Freppaz, M., Williams, B. L., Edwards, A. C., Scalenghe, R., and Zanini, E.: Labile nitrogen, carbon, and phosphorus pools and nitrogen mineralization and immobilization rates at low temperatures in seasonally snow-covered soils, Biol. Fert. Soils, 43, 519-529, 2007.

Gao, Y. H., Chen, H., Luo, P., Wu, N., and Wang, G. X.: Effect of grazingin tensity on biomass of alpine meadow and its allocation in the northwestern sichuan, J. Ecol. Rural Environ., 24, 26-32, 2008.

Gherardi, L. A., Sala, O. E., and Yahdjian, L.: Preference for different inorganic nitrogen forms among plant functional types and species of the Patagonian steppe, Oecologia, 173, 1075-1081, 2013.

Henry, H. A. L.: Climate change and soil freezing dynamics: historical trends and projected changes, Climatic Change, 87, 421-434, 2008.

Hidy, G. M.: Snowpack and precipitation chemistry at high altitudes, Atmos. Environ., 37, 1231-1242, 2003.

Hofstede, R. G. M., Chilito, E. J., and Sandovals, E. M.: Vegetative structure, microclimate, and leaf growth of a páramo tussock grass species, in undisturbed, burned and grazed conditions, Vegetatio, 119, 53-65, 1995.

Igbinosa, E. O.: Effect of cassava mill effluent on biological activity of soil microbial community, Environ. Monit. Assess., 187, 4651-4651, 2015.

Jaeger, C. H., Monson, R. K., Fisk, M. C., and Schmidt, S. K.: Seasonal partitioning of nitrogen by plants and soil microorganisms in an alpine ecosystem, Ecology, 80, 1883-1891, 1999.

Jefferies, R. L., Walker, N. A., Edwards, K. A., and Dainty, J.: Is the decline of soil microbial biomass in late winter coupled to changes in the physical state of cold soils?, Soil Biol. Biochem., 42, 129-135, 2010.

Jones, D. L. and Willett, V. B.: Experimental evaluation of methods to quantify dissolved organic nitrogen (DON) and dissolved organic carbon (DOC) in soil, Soil Biol. Biochem., 38, 991-999, 2006.

Körner, C.: Alpine Plant Life: Functional Plant Ecology of High Mountain Ecosystems, Springer, 2003.

Larsen, K. S., Jonasson, S., and Michelsen, A.: Repeated freezethaw cycles and their effects on biological processes in two arctic ecosystem types, Appl. Soil Ecol., 21, 187-195, 2002.

Larsen, K. S., Grogan, P., Jonasson, S., and Michelsen, A.: Respiration and Microbial Dynamics in Two Subarctic Ecosystems during Winter and Spring Thaw: Effects of Increased Snow Depth, Arct. Antarct. Alp. Res., 39, 268-276, 2007.

Li, F. D.: Experimental technique in agricultural microbiology, China Agriculture Press, Beijing, 1996.

Lin, X. G.: Principles and methods of soil microbial research, Higher Education Press, Beijing, 2010.

Lipson, D. A. and Schmidt, S. K.: Seasonal changes in an alpine soil bacterial community in the Colorado Rocky Mountains, Appl. Environ. Microb., 70, 2867-2879, 2004.

Lipson, D. A., Schmidt, S. K., and Monson, R. K.: Links between microbial population dynamics and nitrogen availability in an alpine ecosystem, Ecology, 80, 1623-1631, 1999.

Lipson, D. A., Schadt, C. W., and Schmidt, S. K.: Changes in soil microbial community structure and function in an alpine dry meadow following spring snow melt, Microb. Ecol., 43, 307314, 2002.

Lu, R. K.: Soil and Agro-Chemical Analytical Methods, Beijing, China Agricultural Science and Technology Press, 2000.

Matthew Robson, T., Baptist, F., Clement, J. C., and Lavorel, S.: Land use in subalpine grasslands affects nitrogen cycling via changes in plant community and soil microbial uptake dynamics, J. Ecol., 98, 62-73, 2010.

Mellander, P. E., Lofvenius, M. O., and Laudon H.: Climate change impact on snow and soil temperature in boreal Scots pine stands, Climatic Change, 85, 179-193, 2007.

Miller, A. E., Schimel, J. P., Sickman, J. O., Skeen, K., Meixner, T., and Melack, J. M.: Seasonal variation in nitrogen uptake and 
turnover in two high-elevation soils: mineralization responses are site-dependent, Biogeochemistry, 93, 253-270, 2009.

Murata, T., Tanaka, H., Yasue, S., Hamada, R., Sakagami, K., and Kurokawa, Y.: Seasonal variations in soil microbial biomass content and soil neutral sugar composition in grassland in the Japanese Temperate Zone, Appl. Soil Ecol., 11, 253-259, 1999.

Nemergut, D. R., Costello, E. K., Meyer, A. F., Pescador, M. Y., Weintraub, M. N., and Schmidt, S. K.: Structure and function of alpine and arctic soil microbial communities, Res. Microbiol., 156, 775-784, 2005.

Norman, R. J., Edberg, J. C., and Stucki, J. W.: Determination of Nitrate in Soil Extracts by Dual-wavelength Ultraviolet Spectrophotometry, Soil Sci. Soc. Am. J., 49, 1182-1185, 1985.

Oquist, M. G., Sparrman, T., Klemedtsson, L., Drotz, S. H., Grip, H., Schleucher, J., and Nilsson, M.: Water availability controls microbial temperature responses in frozen soil $\mathrm{CO}_{2}$ production, Glob. Change Biol., 15, 2715-2722, 2009.

Panikov, N. S., Flanagan, P. W., Oechel, W. C., Mastepanov, M. A., and Christensen, T. R.: Microbial activity in soils frozen to below $-39^{\circ} \mathrm{C}$, Soil Biol. Biochem., 38, 785-794, 2006.

Rinnan, R., Michelsen, A., Baath, E., and Jonasson S.: Mineralization and carbon turnover in subarctic heath soil as affected by warming and additional litter, Soil Biol. Biochem., 39, 3014 3023, 2007.

Sah, R. N.: Nitrate-Nitrogen Determination-A Critical Review, Commun. Soil Sci. Plan., 25, 2841-2869, 1994.

SAS Institute Inc.: SAS 9.2 user's guide, Carolina, USA, 2008.

Schadt, C. W., Martin, A. P., Lipson, D. A., and Schmidt, S. K.: Seasonal dynamics of previously unknown fungal lineages in tundra soils, Science, 301, 1359-1361, 2003.

Schmidt, S. K. and Lipson, D. A.: Microbial growth under the snow: Implications for nutrient and allelochemical availability in temperate soils, Plant Soil, 259, 1-7, 2004.
Schmidt, S. K., Costello, E. K., Nemergut, D. R., Cleveland, C. C., Reed, S. C., Weintraub, M. N., Meyer, A. F., and Martin, A. M.: Biogeochemical consequences of rapid microbial turnover and seasonal succession in soil, Ecology, 88, 1379-1385, 2007.

Soil Survey Staff: Keys to Soil Taxonomy, 12th Edn., USDANatural Resources Conservation Service, Washington, DC, 2014.

Walker, M. D., Webber, P. I., Arnold, E. H., and Ebert-May, D.: Effects of interannual climate variation on aboveground phytomass in alpine vegetation, Ecology, 75, 393-408, 1994.

Wang, J., Xu, B., Wu, Y., Gao, J., and Shi, F.: Flower litters of alpine plants affect soil nitrogen and phosphorus rapidly in the eastern Tibetan Plateau, Biogeosciences, 13, 5619-5631, https://doi.org/10.5194/bg-13-5619-2016, 2016.

Williams, M. W. and Tonnessen, K. A.: Critical loads for inorganic nitrogen deposition in the Colorado Front Range, USA, Ecol. Appl., 10, 1648-1665, 2000.

$\mathrm{Wu}, \mathrm{Y}$. and Onipchenko, V. G.: The structure of plant communities according to soil properties in the eastern Tibetan plateau, Trans. Tebe. State Bios. Rese. Russ., 30, 57-73, 2005.

Yanai, Y., Toyota, K., and Okazaki, M.: Effects of successive soil freeze-thaw cycles on soil microbial biomass and organic matter decomposition potential of soils, Soil Sci. Plant Nutr., 50, 821829, 2004.

Yang, X. X., Ren, F., Zhou, H. K., and He, J. S.: Responses of plant community biomass to nitrogen and phosphorus additions in an alpine meadow on the Qinghai-Xizang Plateau, Chin. J. Plant Ecol., 38, 159-166, 2014.

Yang, Z., Gao, J., Yang, M., and Sun, Z.: Effects of freezing intensity on soil solution nitrogen and microbial biomass nitrogen in an alpine grassland ecosystem on the Tibetan Plateau, China, J. Arid Land, 8, 749-759, 2016. 